\title{
Amelioration of Uranyl Acetate Induced Toxicity on Male Rats by Using Hypericum Perforatum Herb
}

\author{
Abeer E Elkhamisy \\ Assistant Professor of Nutrition and Food Science \\ Faculty of Specific Education, Home Economics Dept., Port Said University, \\ Egypt.
}

\section{ABSTRACT}

The present study was performed to estimate the protective effect of hypericum perforatum (HCP) powder and its oil against uranyl acetate induced toxicity in male rats. Thirty male Albino rats were divided into two groups, group (1) $(n=6)$ normal control. Group (2) $(n=24)$ control positive were daily treated for 28 days with uranyl acetate $75 \mathrm{mg} / \mathrm{kg} / \mathrm{rats} /$ day by oral intubation then divided into four groups: group (2) control positive (untreated)., group (3) $\mathrm{HCP}$ powder $5 \mathrm{mg} \mathrm{kg}$ /diet., group (4) HCP oil $5 \mathrm{ml} \mathrm{kg} / \mathrm{rats}$. Group (5) mixture HCP powder $\mathrm{mg} \backslash \mathrm{kg} / \mathrm{diet} \&$ oil $5 \mathrm{ml} / \mathrm{kg} / \mathrm{rats}$.

The protective groups showed significant decrease in serum total cholesterol, triglycerides, LDL cholesterol, ALT, AST, urea, creatinine, uric acid, and MDA. While body weight gain (BWG), HDL cholesterol, SOD and GSH were significantly increased compared to $(+v e)$ group. The HCP powder $\&$ oil are readily available supplier of polyphenols with great antioxidative are considered as functional food ingredients since they affect physiological and biochemical processes in rats and human beings, resulting in better health and improved the symptoms of uranyl acetate toxicity and prevent its complications. So, this research suggest that the anti-inflammatory and antioxidant properties of HCP are dependent on the flavonoid contents of the HCP.

Key words: Hypericum perforatum L- Uranyl Acetate - Antioxidative Flavonoid. 


\section{INTRODUCTION}

Uranium is radioactive metallic element of high specific gravity. It is chemically classified as a heavy metal and weakly radioactive. Uranium is found as an oxide, uraninite or mixed oxide, pitchblende or complex salt. Occurs in nature as in rocks, soil, rivers, oceans, plants and animals. Consequently, all humans are exposed to naturally occurring uranium through ingestion, inhalation and skin contact (Craft, 2004). Internalized in the body, the soluble components migrate throughout the body and uranium concentrates in the bone, kidney, and liver. When the uranium enters the body, it binds with bicarbonate and proteins. This binding action helps prevent soluble uranium from interacting with most body tissues (Gilman, et al., 2009). Uranium from the environment enters the human body by ingestion with food and drink and by inhalation of respirable airborne uranium-containing dust particles or aerosols (Domingo, et al., 2004)

Hypericum perforatum $L$. is widely distributed through temperate areas of the world, such as North Africa, western Asia and Europe. It contains flavonoids, tannins and essential oil Pavlovic et al., (2006).Hypericum perforatum (HCP) contains many compounds, such as coumarins, unsaturated fatty acids, polyacetylenic derivatives, aphrodisiac, aperient, and sesquiterpenes. Therefore, it has various pharmacological activities, such as cholagogue, stomachic, diuretic, and tonic effects (Baba, et al., 2005). Hypericum perforatum (HCP) is highly considered as antioxidant, seeds and herbs. Results revealed that there is a positive correlation between the total antioxidant and their phenolic and flavonoid contents (Righetti, et al., 2008). Flavonoids are potent antioxidants, free radical scavengers, and metal chelators and inhibit lipid peroxidation. Phenolic compounds are considered as a major group of antioxidant molecules that contribute to the antioxidant activities of herbs and oil of their ability to scavenge free radicals. Hypericum perforatum (HCP) have possess therapeutic effects in different areas and it could be considered as beneficial source of materials for human health. Mazandarani $\boldsymbol{e t}$ al., (2012). Plant essential oils and its extracts have been used for many thousands years, particularly in pharmaceuticals, food preservation, and natural therapies (Imelouane, et al., 2010 and Junko and Toshio, 2011). Moreover, Essential oils also are potential sources of novel antimicrobial compounds especially against bacterial pathogens.

The volatile compounds in tubers of HCP have been investigated previously. Hence, an investigation of the volatile compounds present in tubers 
and leaves species can give a better understanding of the compounds present. Therefore, this paper study the amelioration of uranyl acetate induced toxicity on male rats by using Hypericum perforatum herb as well as the chemical composition of essential oils of the tubers and leaves species of HCP growing in Ukraine (MacLeod and Gonzalez, 1982, Bruggink, et al., 2005 and Javier, et al., 2011).

\section{MATERIALS AND METHODS}

\section{- Materials:}

Hypericum perforatum $L$. powder and oil were obtained from Agricultural Seeds, Medicinal Plants and Herbs Company, Cairo, Egypt. Uranyl acetate was obtained from SIGMA Company for Pharmaceutical Industries Cairo, Egypt. 30 rats male_albino rats of Sprague Dawley strain weighing $(150 \pm 10 \mathrm{~g})$ were purchased from Agricultural Research Center, Giza, Egypt. The rats were provided ad libitum with tap water and were fed with standard diet.

\section{-Methods:}

-Preliminary phytochemical screening of crude extracts of volatile oils and aqueous extracts of HCP: Tannins and resins were detected in the plant sample according to the method of (El-Badrawy, 1996). Saponins substances were detected in different crude extracts under investigation according to the method of (Trease, 1961). Terpenes substances were detected in different crude extracts under investigation according to the method of (Finar, 1968). Flavonoids substances were detected in extracts of different samples using the method of (Geissman, 1962). Carbohydrates and glycosides were treated by Molish test according to the method of (Blabaa, et al., 1976).

\section{Experimental design:}

The experiment was carried out on 30 male Albino rats in two steps, in the first (one week), the rats were divided into two main groups. Control group (6 rats) fed on the basal diet. Control positive group (24 rats) fed on the basal diet and uranyl acetate $75 \mathrm{mg} / \mathrm{kg} / \mathrm{rats} /$ day by oral intubations for 4 weeks (Sarah Ghazi, 2014) rats were then divided into 4 groups (each 6 rats) as follows:

Group (2): Control positive group fed on the basal diet with oral uranyl acetate intubations for 4 weeks.

Group (3): Fed on the basal diet containing $5 \mathrm{mg} \backslash \mathrm{kg} /$ diet $\mathrm{HCP}$ powder with oral uranyl acetate intubations for 4 weeks. 
Group (4): Fed on the basal diet containing $5 \mathrm{ml} / \mathrm{kg} / \mathrm{rats} \mathrm{HCP}$ oil with oral uranyl acetate intubations for 4 weeks.

Group (5): Fed on the basal diet containing mixture of $5 \mathrm{ml} / \mathrm{kg} /$ diet HCP powder and $5 \mathrm{ml} / \mathrm{kg} /$ rats $\mathrm{HCP}$ oil with oral uranyl acetate intubations for 4 weeks.

Body weights of the rats were measured three times a week during the four weeks. The percentage of daily changes in body weights was calculated.

\section{Biochemical analysis:}

Total cholesterol, HDL-cholestrol and triglyceride content were determined by enzymatic colorimetric method according to (Allian, et al., 1974, Richmond, 1973 and Fossati and Principle 1982) respectively. LDLcholestrol and VLDL-cholesterol were calculated by the Friedewald Formula according to (Friedewald, 1972). Plasma alanine and aspartate aminotransferase enzymes activities (ALT and AST) and Bilirubin were determined according to the method of (Reitman and Frankel, 1957). Urea in serum was determined according to (Patton and Crouch, 1997). Serum uric acid and creatinine was estimated an enzymatic method according to (Trinder, 1969 and Henry, 1974). Malondialdehyde (MDA), Superoxide dismutase (SOD) and glutathione (GSH) were analyzed according to the methodes described by Aebi, (1984) ;Nishikimi, et al., (1972) and Beutler, et al., (1963), respectively.

Statistical analysis:

All obtained data were statistically analyzed by SPSS computer software. An analysis of variance ANOVA was used and follow up LSD (SPSS) Computer program variation (Sümbüloglu, et al., 1998).

\section{RESULTS AND DISCUSSION}

Preliminary phytochemical screening of hypericum perforatum (HCP) and aqueous extract

The phytochemical screening of tannins, saponins, resins, terpenes, flavonoids and carbohydrates of HCP oil and aqueous extract were detected and recorded in Table (1). It was noticed that tannins, saponins, resins, terpenes, flavonoids and carbohydrates were found in the HCP oil and powder.

Öztürk, et al., (2009) recommended that, hypericum perforatum, can serve as natural sources to develop the free radical scavengers and might prevent radical attack and therefore has antioxidative effect. Benedi, et al., (2004); Silva, et al., (2017) and Conforti, et al., (2019) found that, there is no previous studies reporting the chemical contents and antioxidant activity. 
Table (1): Preliminary phytochemical screening of hypericum perforatum (HCP) and aqueous extract

\begin{tabular}{|c|c|c|c|c|c|c|}
\hline Type of extract & Terpenes Flavonoids & Tannins & Saponins & Resins & Carbohydrates \\
\hline HCP extract & + & + & + & + & + & + \\
\hline HCP oil & + & + & + & + & + & + \\
\hline
\end{tabular}

+ Present - Absent

Effect of HCP powder and oil on body weight gain, feed intake and feed efficiency ratio of rats administrated uranyl acetate.

Data in Table (2) showed significant decreased in body weight gain and feed intake in control positive group compared with control negative group, while was an increase of feed efficiency ratio (FEP). Among all groups, the highest weight gain (BWG \%) was noticed in the treated group with HCP oil, powder and mixture groups compared with control $(+v e)$ group. These results agreed with Moghaddam, et al., (2016) who reported that there was an increase in body weight gain (BWG) for all treated group rats fed on of HCP oil, powder and mixture tubers comparing with the (+ve) group. The lowest value of the percentage body weight gain \% was $(8.04 \pm 3.31 \%)$ was found in the control positive, while the highest percentage was $(25.69 \pm 2.18)$ recorded for the control negative, The treated rat groups showed that significant increase in body weight gain and feed intake compared with the control $(+)$ groups , while was significant decrease in feed efficiency ratio . The treated rat groups, HCP oil , powder and mixture groups showed that non-significant in body weight gain and feed efficiency ratio (FEP) when compared to normal negative control group (-ve). Felmlee, (2009) and Moghaddam, et al. (2016) who suggested that, the weights of the animals increased significantly.

Table (2): Effect of HCP powder \&oil on body weight $\mathrm{g}, \%$, feed intake and feed efficiency ratio in rats received uranyl acetate

\begin{tabular}{|c|c|c|c|c|}
\hline Parameters & $\begin{array}{c}\text { body weight } \\
\text { gain } \\
(\mathrm{g})\end{array}$ & $\begin{array}{c}\text { BWG } \\
\mathbf{( \% )}\end{array}$ & $\begin{array}{c}\text { feed intake } \\
\text { (FI) } \\
(\mathrm{g} / \mathrm{day})\end{array}$ & $\begin{array}{c}\text { feed efficiency } \\
\text { ratio }\end{array}$ \\
\hline Croups & 38.78 & 25.69 & 18.98 & 0.0048 \\
& \pm 1.4 & \pm 2.18 & \pm 0.64 & \pm 0.003 \\
\hline Control (+) & 12.68 & 8.04 & 15.76 & 0.0124 \\
& \pm 3.4 & \pm 3.31 & \pm 1.39 & \pm 0.003 \\
\hline HCP powder & 36.8 & 23.38 & 19.90 & 0.0054 \\
& $\pm 2.5^{* *}$ & $\pm 4.59^{* * *}$ & \pm 0.45 & \pm 0.004 \\
\hline HCP oil & 35.90 & 22.21 & 19.43 & 0.0054 \\
& $\pm 4.20^{* *}$ & $\pm 9.65^{* *}$ & \pm 0.67 & $\pm 0.004^{* *}$ \\
\hline mixture & 35.37 & 22.81 & 18.65 & 0.0052 \\
& $\pm 3.3^{* *}$ & $\pm 2.69^{* *}$ & \pm 1.24 & \pm 0.003 \\
\hline
\end{tabular}

Each value is the mean + SD of 6 rats. Significant with control group ${ }^{*} p<0.05 * * P<0.01$ 


\section{Effect of HCP powder and oil on serum lipids pattern of rats administrated uranyl acetate.}

Data in Table (3) showed administration of uranyl acetate to normal rats resulted in a significant increase in serum total cholesterol, triglyceride and LDL, VLDL cholesterol levels in control positive group compared with control negative group. The present data showed that uranyl acetate groups, receiving HCP mixture powder and oil , HCP powder and HCP oil had significantly lowered levels of serum total cholesterol, triglyceride and LDL,VLDL cholesterol compared to uranyl acetate group (+ve). These results agree with Santos-Gallego and Badimón (2012) who reported the beneficial effects of HCP in lowering cholesterol in serum. While Moghaddam, et al., (2016) found no benefit of using on blood cholesterol and triglycerides. HCP application both in feed and water combined being most effective in lowering the total blood cholesterol than the other application methods. On the other hand, significant increase in HDL-cholesterol for rats receiving mixture with HCP powder \& oil, $\mathrm{HCP}$ powder and $\mathrm{HCP}$ oil groups compared to uranyl acetate control $(+\mathrm{ve})$.

Results in Table (3), also indicated that all the protective groups HCP powder \& oil showed decrease in atherogenic indexes (TC / HDLc and LDLc / HDLc) compared to uranyl acetate control (+ve). The hypolipidaemic effect of HCP may be due to increasing fecal lipid excretion and decreasing lipid absorption, Cieslik, and Filipiak-Florkiewiez (2002). Santos-Gallego and Badimón, (2012) proved that, an inverse relationship between low concentration of HDL-C and an increased risk for cardiovascular diseases (CVD). Arts, et al., (2011) found that, there was a strong inverse association between the intake of catechin and death from coronary heart disease, this inverse association was most pronounced in human at low risk of coronary heart disease.

Table (3): Effect of HCP powder \&oil on serum lipids pattern in rats received uranyl acetate

\begin{tabular}{|c|c|c|c|c|c|c|c|}
\hline Parameters & $\begin{array}{c}\text { TC } \\
\text { Groups }\end{array}$ & $\begin{array}{c}\text { TG } \\
(\mathbf{m g} / \mathbf{d l})\end{array}$ & $\begin{array}{c}\text { LDL-c } \\
(\mathbf{m g} / \mathbf{d l})\end{array}$ & $\begin{array}{c}\text { HDL-c } \\
(\mathbf{m g} / \mathbf{d l})\end{array}$ & $\begin{array}{c}\text { VLDL-c } \\
(\mathbf{m g} / \mathbf{d l})\end{array}$ & $\begin{array}{c}\text { TC/ } \\
\text { HDLc }\end{array}$ & $\begin{array}{c}\text { LDL/ } \\
\text { HDLc }\end{array}$ \\
\hline Control (-) & 80.01 & 90.34 & 23.16 & 38.34 & 18.12 & 2.07 & 0.62 \\
& \pm 26.67 & \pm 9.8 & \pm 5.7 & \pm 1.5 & \pm 2.01 & \pm 0.01 & \pm 0.20 \\
\hline Control (+) & 100.01 & 175.16 & 40.33 & 23.34 & 35.12 & 4.28 & 1.77 \\
& \pm 33.33 & \pm 13.76 & \pm 17.97 & \pm 4.69 & \pm 3.01 & \pm 1.42 & \pm 0.59 \\
\hline HCP powder & 92.85 & 115.34 & 36.40 & 31.87 & 23.87 & 2.91 & 1.16 \\
& $\pm 30.95^{*}$ & $\pm 8.2^{*}$ & \pm 4.81 & $\pm 2.1^{* *}$ & \pm 1.93 & \pm 0.97 & \pm 0.02 \\
\hline HCP oil & 90.01 & 120.17 & 33.45 & 29.38 & 24.26 & 3.06 & 1.12 \\
& \pm 30.00 & $\pm 11.2^{*}$ & \pm 9.6 & $\pm 3.7^{*}$ & \pm 2.02 & \pm 1.02 & \pm 0.04 \\
\hline Mixture & 80.93 & 94.43 & 26.67 & 34.60 & 18.86 & 2.33 & 0.78 \\
& $\pm 26.97^{* *}$ & $\pm 7.1^{* *}$ & $\pm 5.9^{* * *}$ & $\pm 2.34^{* *}$ & \pm 1.73 & \pm 0.78 & \pm 0.01 \\
\hline
\end{tabular}

Each value is the mean+ SD of 6 rats. Significant with control group *p< $0.05 * * P<0.01$

TC: Total cholesterol TG: Triglyceride

HDLc: High density lipoprotein cholesterol

LDLc: Low density lipoprotein cholesterol VLDLc: Very low density lipoprotein cholesterol 
Effect of HCP powder and oil on serum ALT, AST, bilirubin, urea, creatinine and uric acid of rats administrated uranyl acetate.

Data in Table (4) showed significant increase of ALT, AST, Bilirubin ,Urea, Creatinine and Uric acid in control positive group compared with control negative group, while was significant decrease $(\mathrm{P}<0.01)$ in ALT level for rats receiving mixture of $21.64 \pm 7.4 \mathrm{U} / \mathrm{ml}$ when compared to rats of +ve control which administrated uranyl acetate it $30.82 \pm 4.29 \mathrm{U} / \mathrm{ml}$.

As clear from Table (4) significant decrease $(\mathrm{P}<0.01)$ and $(\mathrm{p}<0.05)$ in AST were observed in the groups treated with mixture of $26.40 \pm 3.93 \mathrm{mg} / \mathrm{dl}$ and HCP powder was $39.26 \pm 7.2 \mathrm{mg} / \mathrm{dl}$ when compared with rats administrated uranyl acetate which was $45.4 \pm 3.50 \mathrm{mg} / \mathrm{dl}$ (+ve control group). Therefore, it is possible to suggest that these extracts are safe and might have protection against hepato cellular damage as evidenced by normal serum levels of AST and ALT. A low significant decrease $(\mathrm{P} \leq 0.01)$ and $(\mathrm{p}<0.05)$ in serum urea and creatinine and uric acid levels in mixture group and HCP oil were detected in comparing with positive control. Renal toxicity is a major adverse effect of uranium, and the metal has toxic effects on the liver as well. These results are in agreement with those reported by Eid, (2009) who found a significant decrease in serum creatinine for groups fed on different levels (5, 10 and 15\%) of HCP. On the other hand, it has been found that decrease in bilirubin for group treated with mixture, HCP powder, HCP oil compared with control positive group Table (4). It was likely that the antioxidant activity of the extracts produced better response in such stressful conditions. These results are near from Domingo, et al.,( 2014 ) which gives an indication on the hepatotoxic effect of uranyl acetate of rats recieved intragastrically $75 \mathrm{mg} / \mathrm{kg} / \mathrm{b} . \mathrm{w}$ uranyl nitrate. These results of treatments are in agreement with those reported by El-Hofi ، (2005). The results in this study are in contrasted with the results of Smit, et al., (1987) who observed an increase in plasma levels of ALT and AST when rats were exposed to depleted uranium in their drinking water. These contradictory results are probably due to the quantity of uranium used and the duration of contamination. 
Table (4): Effect of HCP powder \&oil on serum ALT, AST, bilirubin urea, creatinine and uric acid in rats received uranyl acetate

\begin{tabular}{|c|c|c|c|c|c|c|}
\hline Parameters & $\begin{array}{c}\text { ALT } \\
\text { Groups }\end{array}$ & $\begin{array}{c}\text { AST } \\
(\mathbf{m g} / \mathbf{d l})\end{array}$ & $\begin{array}{c}\text { Bilirubin } \\
(\mathbf{m g} / \mathbf{d l})\end{array}$ & $\begin{array}{c}\text { Urea } \\
(\mathbf{m g} / \mathbf{d l})\end{array}$ & $\begin{array}{c}\text { Creatinine } \\
(\mathbf{m g} / \mathbf{d l})\end{array}$ & $\begin{array}{c}\text { Uric Acid } \\
(\mathbf{m g} / \mathbf{d l})\end{array}$ \\
\hline Control (-) & 12.45 & 28.40 & 0.45 & 12.25 & 0.80 & 2.83 \\
& \pm 5.85 & \pm 4.8 & \pm 0.03 & \pm 2.9 & \pm 0.10 & \pm 0.38 \\
\hline Control (+) & 30.82 & 45.4 & 1.02 & 29.70 & 2.64 & 4.04 \\
& \pm 4.29 & \pm 3.50 & \pm 0.03 & \pm 3.2 & \pm 0.15 & \pm 0.58 \\
\hline HCP powder & 28.17 & 39.26 & 0.55 & 25.17 & 2.31 & 3.23 \\
& \pm 7.8 & \pm 7.2 & $\pm 0.09 * *$ & \pm 3.7 & \pm 0.18 & \pm 0.4 \\
\hline HCP oil & 29.59 & 38.19 & 0.62 & 26.13 & 2.25 & 3.18 \\
& \pm 5.0 & \pm 6.1 & \pm 0.05 & \pm 3.6 & \pm 0.17 & \pm 0.5 \\
\hline Mixture & 21.64 & 26.40 & 0.44 & 23.72 & 1.07 & 2.54 \\
& $\pm 7.4 * *$ & $\pm 3.93 * *$ & $\pm 0.06 * *$ & $\pm 2.6 * *$ & $\pm 0.11 * *$ & $\pm 0.6^{* *}$ \\
\hline
\end{tabular}

Effect of HCP powder and oil on antioxidant and oxidative stress parameters of rats administrated uranyl acetate.

As evident from Table (5) Showed significant decreased in (SOD) and (GSH) in control positive group compared with control negative group, While was an increase of malondialdehyde (MDA). There was significant decrease $p<$ 0.05 in malondialdehyde (MDA) were observed in rats fed on mixture group of compared with positive control in which superoxide dismutase (SOD) revealed an increase significantly $(\mathrm{P}<0.001)$ and $(\mathrm{P}<0.01)$ in treated groups when compared with control +ve group administrated uranyl acetate.

Treating rats with $\mathrm{HCP}$ protective after induction of uranyl acetate showed significant increase in glutathione $(\mathrm{GSH})(\mathrm{P}<0.01$, this was observed on rats fed on mixture group comparing with positive control, also a significant increase $(\mathrm{P}<0.05)$ were observed in rats fed on mixture, HCP powder and oil.

From the present study, we can conclude that $\beta$-bisabolene and other volatile oils or supertences $(70.7 \%$ and $63.1 \%$ respectively) were the major components in the essential oil of HCP leaves, would play an important role as an the antioxidant activity (Abd El-Aziz, et al., 2015). 
Table (5) Effect of HCP powder and oil on antioxidant and oxidative stress parameters in rats received uranyl acetate

\begin{tabular}{|c|c|c|c|}
\hline \begin{tabular}{|ll} 
Groups & Parameters \\
\end{tabular} & $\begin{array}{l}\text { SOD } \\
(\mathrm{mg} / \mathrm{L})\end{array}$ & $\begin{array}{c}\text { GSH } \\
(\mathrm{U} / \mathrm{mL})\end{array}$ & $\begin{array}{c}\text { MDA } \\
(\mathbf{U} / \mathbf{m L})\end{array}$ \\
\hline Control (-) & $\begin{array}{c}0.54 \\
\pm 0.12\end{array}$ & $\begin{array}{l}9.27 \\
\pm 0.6\end{array}$ & $\begin{array}{l}11.26 \\
\pm 1.4\end{array}$ \\
\hline Control (+) & $\begin{array}{c}0.26 \\
\pm 0.09\end{array}$ & $\begin{array}{c}4.22 \\
\pm 1.54\end{array}$ & $\begin{array}{l}19.2 \\
\pm 0.8\end{array}$ \\
\hline HCP powder & $\begin{array}{c}0.67 \\
\pm 0.05^{* * *}\end{array}$ & $\begin{array}{l}5.07 \\
\pm 1.5\end{array}$ & $\begin{array}{c}14.4 \\
\pm 1.09\end{array}$ \\
\hline HCP oil & $\begin{array}{c}0.65 \\
\pm 0.17 * * *\end{array}$ & $\begin{array}{c}5.16 \\
\pm 0.69\end{array}$ & $\begin{array}{l}15.6 \\
\pm 0.9\end{array}$ \\
\hline Mixture & $\begin{array}{c}0.75 \\
\pm 0.2 * * *\end{array}$ & $\begin{array}{c}7.7 \\
\pm 0.88^{* *}\end{array}$ & $\begin{array}{c}12.5 \\
\pm 1.7^{*}\end{array}$ \\
\hline
\end{tabular}

\section{CONCLUSION:}

From the previous results this research can conclude that the administration by uranyl acetate has a negative effects, and the active components of HCP powder, oil and mixture reflects an important role in the inhibition of these effects on the different parameters that has been taken in consideration in this study. HCP may be contain more free radical scavenging molecules and it can be used as a potential source of natural antioxidants and nutrients. Its use as a natural antioxidant source appears to be an alternative to synthetic antioxidants. This study could be useful for further exploitation and application of the HCP powder, oil and mixture.

\section{REFRENCES:}

Abd El-Aziz, A. D.; Elsayed, Z.I.;Zahra, M.H.; Shalaby, A.A. and Mohamed, E.F. (2015): Biological study of the extract of some species of vitex agnus-castus Kafmurium grown in Egypt. Int, J. of Pharma Sci. and Res. (IJPSR)., 6 (2):230.

Aebi, H.,(1984): Catalase in vitro. Methods Enzymol., 5: 121-126.

Allian, C.A.; Poon, S.; Chan, C. S. G. Richmond, W. and Fu, P.C (1974): Enzymatic determination of total serum cholesterol. Clinical Chemistry 20:4705. 
Arts, C.W.; Hollman, C.H.; Feskens, J.M. and Kromhout, D. (2011): Catechin intake might explain the inverse relation between tea consumption and ischemic heart disease: the Zutphen Elderly Study, Am J. of Clin Nutr., 74 (2): 227-232.

Baba H, Yaoita Y. And Kikuchi M. (2005). Sesquiterpenoids from the leaves of Helianthus tuberosus L. J Tohoku Pharm Univ.52:21-5.

Benedi, J.; Arroyo, R.; Romero, C.; Martin-Aragon, S. and Villar, AM. (2004): Antioxidant properties and protective effects of a standardized extract of Hypericum perforatum on hydrogen peroxide-induced oxidative damage in PC12 cells., J. of Life Sci., 75: 1263-1276.

Beutler, E.; Duron,O. and Kelly, B. (1963): Improved method for the determination of blood glutathione. J. Lab. Clin. Med., 61: 882-88

Blabaa, S., Hilal, S. H. and Zaki, A. Y. (1976): Medicinal plant constituents. 2nd end. General Organization for University and Schoolbooks, Cairo;147-156.

Bruggink, C, Maurer,R. ,Herrmann, H, Cavalli,S. and Hoefler,F (2005). Analysis of carbohydrates by anion exchange chromatography and mass spectrometry, J Chromatogr.1085(1):104-9 .

Cieslik, E. and Filipiak-Florkiewiez , A. (2002). Prospective usage of Jerusalem Artichoke ( Helianthus tuberosus L.) for producing functional food . Review Zywnosc.,7 (1) :73-81.

Conforti, F.; Statti, GA.; Tundis-Bianchi, RA.; Agrimontib, C.; Sacchetti, G.; Andreotti, E.; Menichini, F. and Poli F. (2019): Comparative chemical composition and variability of biological activity of methanolic extracts from hypericum perforatum L. J. of Nat Prod Res., 19: 295-303.

Craft, E. (2004): Depleted and natural Uranium: Chemistry toxilogical effects. J. Toxic. Environ. Health, 7(4):297-317

Domingo, J. L.; Liobet, J. M.; Tomas, J. M. \& Corblla, J. (2004): Acute toxicity of uranium in rat and mice. Bull Environ. Contam. Toxical., 39: 168174.

Eid A. Z. (2009) . Physiological Response to Diets Fortified with Jerusalem Artichoke Tubers ( Helianthus tuberosus L.) Powder by Diabetic Rats American -Eurasian J.Agric.\&Environ .Sci.,5(5):682-688. 
El-Badrawy, E.S.E.B.Y. (1996): Biochemical studies on some natural plant products. Ph.D. Thesis, Fac. of Agric., Mansoura Univ., Egypt.

El-Hofi, A.A. (2005). Technological and biological uses of Jerusalem artichoke powder and resistant Starch. Annals of Agric. Sc. Moshtohor, 43(1): 279-291.

Felmlee, M.A. (2009): Effects of the flaxseed lignans secoisolariciresinol diglucoside and its aglycone on serum and hepatic lipids in hyperlipidaemic rats. Br J. of Nutr., 102(3): 361-369.

Finar, L. (1968). Organic chemistry, 4th edn. Longmanns green and Co., London.

Fossati, P. and Principle, L. (1982). Estimation of the concentration of triglyceride in plasma and liver. Clinical Chemistry 28: 2077- 81.

Friedewald F.D.S. (1972). Estimation of the plasma low density lipoprotein cholesterol without use of the preparative ultracentrifuge. Clinical Chemistry18:499- 502.

Geissman, A. (1962). Chemistry of flavonoid compounds. Macmillan and Co. New York, 72.

Gilman, A. P.; Villenenve, D. C.; Secours, V. E.; Yagminas, A. P.; Tracy, B. L.; Quinn, J. M.; Valli, V. E.; Willes, R. J. and Moss, M. A. (2009): Uranyl Nitrate: 91-day exposure and recovery studies in the male New Zealand white rabbit. Toxicol. Sci., 41(1): 138-151.

Henry, R.J. (1974). Clinical chemistry, Principles and technis 2nd Edition Harper and row 525.

Imelouane , B., EL Bachiri , A., Wathelet ,E . and Jean -Paul (2010). Chemical composition, cytotoxic and antioxidant activity of the essential oil of Lavandula dentate. World Journal of Chemistry, 5(2) :103-110.

Javier, M., Jerónimo ,G ., Luis , R ., Rafael ,A.B .(2011) .Analysis of sugars by liquid chromatography-mass spectrometry in Jerusalem artichoke tubers for bioethanol production optimization. Biomass Bioenergy. 35(5) 20062012. 
Junko, T., and Toshio, N.(2011). Preparation of dried chips from hypericum perforatum and analysis of their functional properties. Food Chem .126(3):9226.

Macleod ,A.J.,and Gonzalez De Troconis ,N.(1982). Volatile flavor components of cashew "Apple" (Amacardium occidentale) phytochemistry $.21: 2527-2530$.

Mazandarani, M.; Moghaddam, Z.; Zolfaghari, M.R.; Ghaemi E.A. and Bayat, H. (2012): Effects of solvent type on phenolics and flavonoids content and antioxidant activities In onosma dichroanthum boiss. J. of Med Plants Res., 6: 4481-4488.

Moghaddam, M.H.G.; Roghani, M. and Maleki, M. (2016): Effect of Hypericum perforatum aqueous extracts on serum lipids, aminotransferases, and lipid peroxidation in hyperlipidemic rats, J. of Res Cardiovasc Med., 5(2): 31326.

Niskikimi, M.,Rao,N.A and Yagii, k . (1972). The occurance of superoxide anion in the reaction of reduced phenazine metho-sulfate and molecular oxygen.Biochem Biophys. Res.Comm:46:849-854.

Öztürk, N.; Tunçel, M. and Potoğlu-Erkara, I. (2009): Phenolic compounds and antioxidant activities of some Hypericum species: A comparative studywith $H$. perforatum. Pharmaceutical Biology., 47(2): $120-127$.

Patton, C.J., and Crouch, S.R. (1997): Enzymatic colorimetric method for determination urea in serum. Anal. Chem., 49: 464.

Pavlovic, M.; Tzakou, O.; Petrakis, P.V. and Couladis, M. (2006): The essential oil of Hypericum perforatum L. , Hypericum tetrapterum Fries, Hypericum olympicum L. growing in Greece. J of Flavour and Fragrance., 21: 84-87.

Reitman, S. and Frankel, S. (1957): Determination of glutamate pyruvat transaminase and glutamate oxaloacetate transaminase. Amer. J. Clin. Path., 28: 56-63.

Richmond, W. (1973): Estimation of free and etherified tissue cholesterol. Clinical Chemistry 19: 1350- 1354. 
Righetti, L., Tassoni, A.and Bagni , N .(2008). Polyamines content in plant derived food: A comparison between soybean and Hypericum perforatum.Food Chem.111(4):852-6.

Santos-Gallego, C.G. and Badimón, J.J. (2012): High-density lipoprotein and cardiovascular risk reduction: Promises and realities. Rev. Esp. Cardiol., 65: 305-308.

Sarah Ghazi A. (2014): Effect of different doses of uranyl acetate on some blood parameters and hepatic enzymesin females rats. Journal of Biotechnology Research Center (8). 34-39.

Silva, B.A.; Ferreres, F.; Malva, J.O. and Dias, A.C.P. (2017): Phytochemical and antioxidant characterization of Hypericum perforatum alcoholic extracts. Food Chemistry., 90: 157-167.

Smit, M., Buursma, A., Bouma, J., and Gruber, M. (1987): Receptormediatedendocytosis of lactate dehydrogenase M4 by liver macrophages: amechanism for elimination of enzymes from plasma. Evidence forcompetition by creatine kinase MM, adenylate kinase, malate andalcohol dehydrogenase. J. Biol. Chem.262:13020-6.

Sümbüloglu, K., Sümbüloglu, V., and Biyoistatistik, E. (1998): 8th edition, HatibogluYayinevi, Ankara. 76-86.

Trease, G.E. (1961): Textbook of pharmacognosybillier, 8th edn. Tindall and Cox., London, 596.

Trinder, P. (1969): Ann Clin Biochem 6-24. 


\section{الملخص}

\section{تحسين السمية الناتجة عن خلات اليورانيل علي ذكور الفئران باستخدام عثبة حشيشة القلب}

أجريت هذه الدراسة لمعرفة الثأثير الوقائى لعشبة حشيشة القلب على السمية الناتجة عن الاصابة بخلات اليورانيل على ذكور الفئران. و تم تقسيم عدد •ب ذكور فئران ألبينو الى مجموعتين اساسيتين :

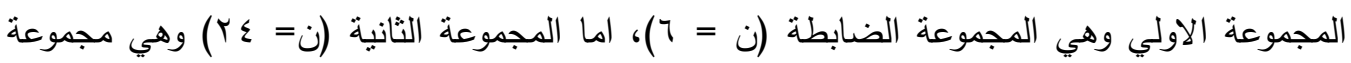

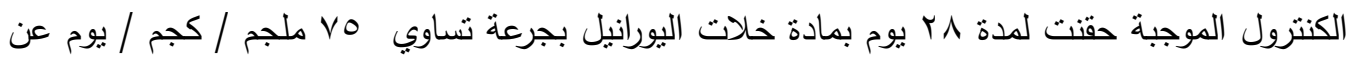

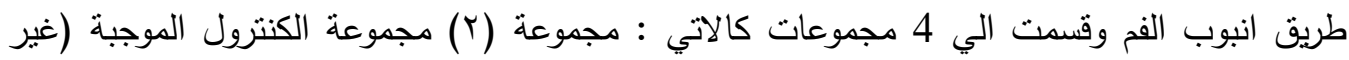

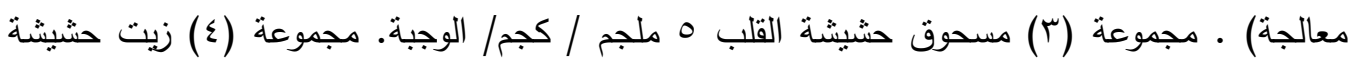

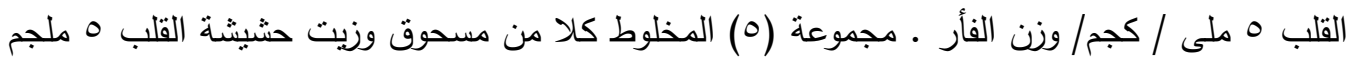
/ كجم/ الوجبة و ه ملي/ كجم /وزن الفأر .

وأظهرت النتائج انه في المجموعات الوقائية حدث انخفاض كبير في مستوي الكولسترول الكلي في الدم

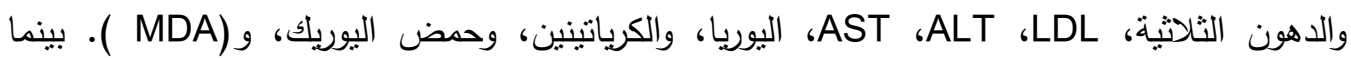

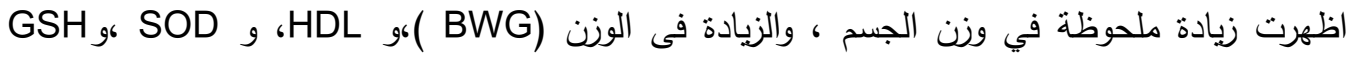

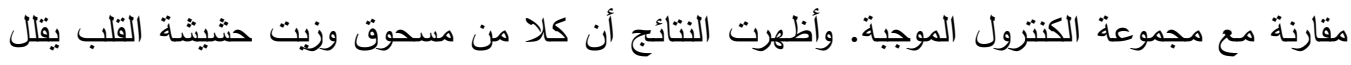
ويحسن من معظم مؤشرات المقاييس الكيموحيوية التي سبيتها خلات اليورانيل حيث عشبة حشيشة القلب وزيتها من الاغذية الوظيفية الغنية بالمركبات الفينولية. الكلمات المفتاحيه: حشيشة القلب -خلات اليورانيل - مضادات الاكسدة - الفلافونويد 